\title{
Social Studies Course from the Perspective of Parents -The Istanbul-Sultanbeyli Case
}

\author{
Kenan Baş ${ }^{1, *}$ \& Esen Durmuş ${ }^{2}$ \\ ${ }^{1}$ Social Studies Education, Institute of Educational Sciences, Firat University, Elaziğ, Turkey \\ ${ }^{2}$ Social Studies Education, Faculty of Education, Firat University, Elaziğg, Turkey \\ *Correspondence: Social Studies Education, Institute of Educational Sciences, Firat University, Elaziğ, Turkey. \\ E-mail: kenanbas2301@gmail.com
}

Received: July 11, 2019

Accepted: August 5, 2019 Online Published: August 15, 2019

doi:10.5430/wje.v9n4p73

URL: https://doi.org/10.5430/wje.v9n4p73

\begin{abstract}
The aim of this study is to identify the perspectives of parents on the "Social Studies" course. The case study design, one of the qualitative research methods, was used in accordance with the nature of the study. Data related to the study were obtained through a semi-structured interview form prepared by the researchers. The data of the study were obtained from the parents of students attending 5th, 6th and 7th grade of a state secondary school located in the Istanbul-Sultanbeyli district in the spring semester of 2017 and 2018 academic year. The data obtained were analyzed by content analysis. According to the data obtained from the research, the following results were obtained: The majority of the parents apparently linked the concept of Social Studies to the concepts of History, Geography, Citizenship and Socialization. Parents thought that the subjects related to History, Geography, Citizenship Rights, Culture, Democracy, Human Rights and the life of Mustafa Kemal Atatürk were taught in the Social Studies course. Nevertheless, it was seen that the parents wished to see the concepts such as Love of Motherland, Nation, Community and National Flag, Etiquette, Cultural Values, Freedom, Democracy, Equality to be taught in the Social Studies courses. While the parents mostly compared the Social Studies courses with such organs as the Brain, Kidney, Heart, Eye, Stomach and Intestine, they considered it as appropriate to place this course in the last places in terms of importance. In addition, it was found that majority of the parents did not want their children to become social studies teachers in the future.
\end{abstract}

Keywords: parents, social studies, course, perspective, citizenship rights

\section{Introduction}

The principle aim of mankind since childhood is to get to know the world in which s/he lives. An important part of his/her life is to discover the objects in the universe instinctively, compare and ask questions about them and learn about these questions from his/her immediate environment and school (Kutluca \& Aydin, 2010, p.66). Human beings possess the capability to think. This ability differentiates the human beings from all other beings. From birth to death, $\mathrm{s} / \mathrm{he}$ carries this ability to various dimensions and expresses himself/herself in many areas. With this ability to express himself/herself, s/he makes his/her mark and socializes with the artifacts s/he has created. S/he forms a society thanks to socialization and cultural interaction occurs. The cultural dimension of the human beings is considered as a sufficient reason for them to become a human and human develops himself/herself in the cultural dimension by interacting with the nature (Demirel, 2011; Gülsoy \& Bulut, 2016). Just in this process of individualization, it is possible for us to say that two concepts emerge. These are the concepts of family and school. Yörükoğlu (1998) defined the concept of family as a stage on which human relations were exhibited. The child observes all the complex aspects of human relations on this stage, and then experiences and learns them. Inam (1992), on the other hand, defines the concept of family as the place where the natural and cultural reality of all kinds are first learned; the very first door to reality; the first scene on the way to the world stage; the very first environment of trust, sharing, communication and social environmental where the actors are recognized; our very first hive where we start to get to know love, disappointment, power, weakness, our body, ourselves, our language (Aktrn \& Aslanargun, 2007, p.121). Undoubtedly, the family factor is one of the most important factors affecting students' all kinds of development and academic success. From this respect, it is of great importance that families closely monitor the development and success of their children 
and integrate them into educational activities in schools (Akbaşlı \& Kavak, 2008; Balkar, 2009; Çelenk, 2003; Ceylan \& Akar, 2010; and Kukk, Rajalaane, Liis Rei, \& Piht, 2015). The second concept that comes into play in the process of adaptation of the individual to social life is the schools. School is an institution that can be the main component of the society or can be considered as a mirror after the family. In today's world where the change is very rapid, school and family should be open to novelties in order to prepare the society for changes (Gülcan \& Taner, 2011; Bayrakdar, 2006). Therefore, when considered specifically in terms of the courses at school, it is seen that social studies course undertakes an important mission in the process of socialization of the individual. Considering the fact that the student is at the heart of the contemporary learning-teaching approach, the student needs to realize what real life is like, understands his/her own role in it and learns to make his/her own decisions. In order for the students to learn these behaviors, they are expected to actively participate in the learning and teaching processes. In this context, it is clearly seen that the 2004 Primary Education Social Studies Program which emphasizes the learner-centeredness encourages the use of concrete tools and materials and gives concrete examples about it (Ayva, 2010, p.276).

Social studies is a field of study that focuses on people and their lives. Since the field of social studies is built on an interdisciplinary basis, it is quite difficult to make a clear and specific definition. However, it is commonly known that there are many definitions about social studies. According to Erden (Undated, p.8), social studies is a field of study in which students in primary education institutions are helped to acquire some knowledge, skills, attitudes and values related to social life in relation to the knowledge and information obtained from the social sciences disciplines in order to raise good and responsible citizens. The social sciences within a curriculum and as a course that emerged in the United States in the early 20th century, was first adopted as interdisciplinary and multidisciplinary program approach and a school course in the late 1960s in Turkey (Öztürk \& Dilek, 2002, p. 72). Even though a course called social studies was included in the elementary school program for the first time in 1968, it is commonly known that before 1968, the contents related to social studies course were presented in such courses as history, geography, civics / nationality / citizenship (Safran, 2011, p. 13). The social studies content that was taught in secondary schools within the syllabus of national history, national geography and civics courses between 1985 and 1997, began to be offered after that date under the name of integrated social studies course (Çetin \& Dinç, 2017). There are different approaches to the teaching of social studies, a course in which knowledge and information obtained from different social science disciplines is presented to students in an integrated structure. Main approaches to the teaching of social studies are defined as social studies as citizenship transfer, social studies as part of social sciences and teaching of social studies as a reflective study (Tay, 2010, p. 14). In the present study that was carried out with parents of 5th, 6th and 7th grade secondary school, it was aimed to identify the perspectives of parents on the "Social Studies" course and the underlying reasons. In order to do this, efforts were exerted to investigate what social studies as a concept and as a course meant for parents; which subjects were included or should be included in the social studies course content and what parents thought about the reflections of social studies to social life. The reason for this is that it is thought that an understanding of the Social Studies curriculum can be proposed with the feedback obtained from the parents and that the present study will contribute to the relevant field in every revision process that will be conducted in the Social Studies curriculum. Furthermore, when the relevant literature on the subject is reviewed, it is assumed that the present study may fill the gap in the field since the studies conducted for parents are almost non-existent.

\section{Aim of the Study}

The aim of this study is to present in detail the opinions of parents of 5th, 6th and 7th grade students about the social studies course. For this purpose, answers to the following questions were sought.

- What does the concept of Social Studies mean to you?

- What do you think a student learns in the Social Studies course?

- As a parent, if you were consulted regarding your opinions while preparing the content of Social Studies course, what subjects and concepts would you suggest to be taught to your child in this course?

- If you thought of the Social Studies course as an organ in the human body, which organ would you describe this course as? Why?

- If you wished to rank all the courses in terms of importance, where would you place the Social Studies course? Why?

- Would you want your child to be a Social Studies teacher? (Yes-No) Why? 


\section{Method}

This section includes information about the research model, study group, data collection tools and data analysis.

\subsection{The Research Model}

The qualitative research method was used in the present study. Qualitative research "is defined as a qualitative data collection method in which data collection tools such as observations, interviews and document analysis are used, and a qualitative process in which perceptions and events are presented in the natural environment in a realistic and holistic way." (Yıldırım \& Şimşek, 2006, p.35). One of the qualitative research methods, case study design, was used in accordance with the nature of the study in the present study. Case study is a method used to answer the how and why questions in cases where current issues and investigator control do not have any impact over the variables (Yin, 2009; Yıldırım \& Şimşek, 2011).

In the sample selection of the study, convenience sampling method, one of the purposeful sampling methods, was used. This sampling method is the sampling technique that is carried out with the existing participants who have the necessary conditions related to the study subject and who are willing to participate in the study (Christensen, Johnson \& Turner, 2015, p. 357).

\subsection{The Study Group}

The present study was carried out on the parents of students attending 5th, 6th and 7th grade level of a public secondary school in the Istanbul-Sultanbeyli district in the spring semester of 2017-2018 academic year. A total of 75 parents participated in the study. Both parents and Social Studies teachers participated in the study on a voluntary basis.

Table 1. Demographic Information Regarding the Participants

\begin{tabular}{|c|c|c|c|c|c|}
\hline \multicolumn{2}{|c|}{ Gender } & \multicolumn{2}{|c|}{ Frequency } & \multicolumn{2}{|c|}{ Percent } \\
\hline \multicolumn{2}{|c|}{ Female } & \multicolumn{2}{|c|}{44} & \multicolumn{2}{|c|}{58,7} \\
\hline \multicolumn{2}{|c|}{ Male } & \multicolumn{2}{|c|}{31} & \multicolumn{2}{|c|}{41,3} \\
\hline \multicolumn{2}{|c|}{ Total } & \multicolumn{2}{|c|}{75} & \multicolumn{2}{|c|}{100,0} \\
\hline \multicolumn{2}{|c|}{ Level of Education } & \multicolumn{2}{|c|}{ Frequency } & \multicolumn{2}{|c|}{ Percent } \\
\hline \multicolumn{2}{|c|}{ Primary School } & \multicolumn{2}{|c|}{42} & \multicolumn{2}{|c|}{56,0} \\
\hline \multicolumn{2}{|c|}{ Secondary School } & \multicolumn{2}{|c|}{16} & \multicolumn{2}{|c|}{21,3} \\
\hline \multicolumn{2}{|c|}{ High School } & \multicolumn{2}{|c|}{11} & \multicolumn{2}{|c|}{14,7} \\
\hline \multicolumn{2}{|c|}{ University and M. A, P. HD } & \multicolumn{2}{|c|}{6} & \multicolumn{2}{|c|}{8,0} \\
\hline \multicolumn{2}{|c|}{ Total } & \multicolumn{2}{|c|}{75} & \multicolumn{2}{|c|}{100,0} \\
\hline \multicolumn{2}{|c|}{ Students' Grade Level } & & ncy & & \\
\hline 5 th & & & & & \\
\hline 6th & & & & & \\
\hline 7 th & & & & & \\
\hline & & & & & \\
\hline Hometown & Frequency & Percent & Hometown & Frequency & Percent \\
\hline Adıyaman & 1 & 1,3 & Malatya & 2 & 2,7 \\
\hline Ağr1 & 1 & 1,3 & Muş & 5 & 6,7 \\
\hline Amasya & 1 & 1,3 & Nevşehir & 3 & 4,0 \\
\hline Ardahan & 3 & 4,0 & Niğde & 2 & 2,7 \\
\hline Bingöl & 3 & 4,0 & Ordu & 4 & 5,3 \\
\hline Bitlis & 3 & 4,0 & Rize & 1 & 1,3 \\
\hline Çankırı & 2 & 2,7 & Samsun & 1 & 1,3 \\
\hline Erzurum & 5 & 6,7 & Sinop & 5 & 6,7 \\
\hline Giresun & 3 & 4,0 & Sivas & 8 & 10,7 \\
\hline Gümüşhane & 5 & 6,7 & Tokat & 2 & 2,7 \\
\hline İstanbul & 3 & 4,0 & Van & 2 & 2,7 \\
\hline İzmir & 1 & 1,3 & Yozgat & 5 & 6,7 \\
\hline Kastamonu & 2 & 2,7 & Total & 75 & 100,0 \\
\hline Kars & 2 & 2,7 & & & \\
\hline
\end{tabular}




\subsection{Data Collection Tool}

In this study, in order to identify the perspectives of parents on the "Social Studies" course, semi-structured interview form prepared by the researchers was used as a data collection tool. The interview form consisted of two parts, which included personal data of the participants and questions that would enable the participants to determine their opinions on the Social Studies course. During the preparation of the interview questions, initially, a field survey was conducted and a list of 8 questions was prepared in line with the expert opinion. In order to check whether the questions were clear and comprehensible (Social Studies Teacher: 3; Turkish Teacher: 1; Educational Programs Faculty: 1) expert opinion was consulted and pilot study was conducted with 6 parents.

After the feedback received from the pilot study with both parents and experts, it was decided that 2 questions were problematic; the number of questions was changed as 6 and the questions in the interview form were finalized. In the next stage, 3 Social Studies teachers who were going to interview with the parents and who taught this course at different grade levels of the same school were interviewed with and the teachers were informed about the interview method and the issues that should or should not be done during the implementation process. Data were collected between 26 February and 20 April 2018. During the implementation phase of the study, first of all, the parents were contacted to identify the parents who would like to participate voluntarily. Afterwards, an appointment was requested for the place and time of the interview with the parents wishing to participate in the study. Care was taken in that the interviews to be made with the parents did not to interfere with the educational activities and the time periods during which it was no working hours or idle classes were considered appropriate for this end. The interviews were mostly conducted in the teachers' room of the school where the teachers worked. However, interviews were conducted with the parents who were busy or not able to make it to the school either at their work places or in their own home environment. The interviews lasted an average of 20-30 minutes. During the interview process, some measures were taken in order for the parents to give sincere answers to the questions and reflect their real feelings and thoughts. Parents were assured that the data obtained from this study would not affect their students' educational life in any way, and that the data obtained would not be given to any institution, person or media, and that interview forms would be given numerical codes and parents' names would not be mentioned at all. Interviews were both audio-recorded and transferred to written form with the consent of the parents. In order to use the time correctly during the interview especially with the parents who spoke very fast and had more than one answer to the question asked, primarily voice recordings were used. After the answers given to the questions were repeated to the parents in summary by the researcher, the study was terminated.

\subsection{Data Analysis}

The raw data obtained from the parents by the researchers were converted into written form and analyzed by the content analysis technique. "Content analysis is defined as a systematic, replicable technique in which some words of a text are summarized in smaller content categories by coding based on certain rules." (Büyüköztürk, Kılıç Çakmak, Akgün, Karadeniz, \& Demirel, 2013; p. 240). In the content analysis technique, similar data are gathered around certain concepts and themes and presented in a format that the reader can understand (Yıldırım \& Şimşek, 2008). In this framework, firstly, the answers given by the parents were coded as P-1 (Parent), P-20, P-44 on the basis of confidentiality. The gender of the parents was indicated by the letters M-F (Male-Female). After all the data were coded, the resulting concepts were organized under certain headings. The data, which were classified according to the themes obtained, were presented with the direct examples used in the interview.

\subsection{Validity and Reliability}

In order for the present study to be a valid and reliable one, first of all, expert opinion was consulted at every stage of the research. However, the data obtained from the parents were analyzed independently and coded by the researchers at different times during the data analyses. Afterwards, these separate encodings were compared and it was found that they were consistent with each other. Furthermore, the fact that data obtained from the interviews were presented in the form of direct citations increases the validity and reliability of the study. It is because in such analyses (content analysis), it is emphasized by many experts that direct quotations should be included in order to reflect the opinions of the interviewees effectively (Altunışık, Coşkun, Bayraktaroğlu, \& Yıldırım, 2002; Yıldırım \& Şimşek, 2011).

\section{Findings}

The opinions of the parents of the 5th, 6th and 7th grade students who participated in the study about Social Studies course are given below. 
4.1 Question 1: What Does the Concept of Social Studies Mean to You?

Table 2. Themes Reflecting Parents' Views

\begin{tabular}{|c|c|c|c|}
\hline Themes & Frequency & Theme & Frequency \\
\hline History & 32 & Geography & 32 \\
\hline General Turkish History & & - Economy & \\
\hline Ottoman History & & - Agricultural Activities & \\
\hline World History & & Citizenship & 15 \\
\hline Socialization & 23 & $\cdot$ Rights, Freedom, Equality & \\
\hline Manners, Customs and Traditions & & Nothing & 5 \\
\hline
\end{tabular}

Parents tried to express their perceptions about the concept of Social Studies by emphasizing the themes of History (f: 32), Geography (f: 32), Socialization (f: 23), Citizenship (f: 15) and Nothing (f: 5). Parents' answers are given below. One of the parents tried to evaluate the idea of social studies from a wide perspective by stating that:

(P-54-M). "Social Studies is a general field that do not have any scientific formula, but in which the unwritten manners, customs and traditions of societies that live together coexist and social rules are internalized. In my opinion, Social Studies is the reflection of social life in the mirror. You can find all the concepts about your life in the Social Studies pool." Another parent, on the other hand, explicated the concept as follows:

(P-13-M). "It is the field of science that puts forward humane and scientific solutions on issues concerning the society and the country, but also develops new rules, evaluates and solves the problems from a social aspect." (V-13-E).

(P-12-M). "In my opinion, the first thing that comes to ones' mind regarding the concept of Social Studies is that it is a course where the subjects of History and Geography are collected under one title and these subjects are taught." Another parent expressed his opinions in the form of internalizing his loyalty and longing for the country's history with the concept of Social Studies as follows:

(P-70-F). "When the terms Social Studies is mentioned, I come to think of our history. I remember our ancestors, especially the Ottoman state. I think about our ancestors. In my opinion, Social Studies means the Friday prayer that Alparslan performed with his white shroud before the battle of Malazgirt. For me, Social Studies means Historical memory. It means the graves of our grandfathers that were not excavated in Çanakkale."

(P-36-F). "Social Studies is a guide that enables the individual to adapt to the geography. I want to explicate this a little more. A student or any individual living in the climate conditions of the region where s/he lives and continues to live in accordance with these climatic conditions through Social Sciences. Our clothes, the way we eat, our skin color, the way we communicate, our position in the world, our awareness of other societies in the world; in short, for me, the concept of Social Studies means the sum of all of them."

4.2 Question 2: What Do You Think a Student Learns in the Social Studies Course?

Table 3. Themes Reflecting Parents' Views

\begin{tabular}{|c|c|c|c|}
\hline Themes & Frequencies & Themes & Frequencies \\
\hline History & 38 & Human Rights & 4 \\
\hline Geography & 38 & Everything & 4 \\
\hline Citizenship Rights & 12 & Life of Ataturk & 4 \\
\hline Culture & 7 & Sociology & 2 \\
\hline Democracy & 4 & & \\
\hline
\end{tabular}

Parents think that students learn the subjects of History (f:38), Geography (f:38), Citizenship Rights (f: 12), Culture (f: 7), Democracy (f: 4), Human Rights (f: 4), Everything (f: 4), Life of Atatürk (f: 4), and Sociology (f: 4) in the Social Sciences course. Responses of the parents to the relevant question are given below. One of the parents indicated that;

(P-7-M). I think that a student learns about democracy in the Social Sciences course. What is democracy? How are the elections organized? How do the local governments function? That is, who govern the provinces and the towns? ... In addition to these, they learn about our past history. They learn about the important names in our history.

(P-55-F). I think that my daughter learns bout sociology in the Social Sciences course. She learns about the unwritten social rules, manners and customs, and our cultural values. Briefly, I think she learns about ways of how to adopt to the 
social life. In addition, I think she learns about the subjects related to History and Geography.

(P-23-F). I would like to emphasize that student learns "individually" in the Social Studies course. S/he learns many things; as a citizen, s/he learns his/her responsibilities to the society, s/he learns about human rights; s/he learns social solidarity in difficult times; s/he learns his/her rights to elect and to be elected.

(P-44-M). Students learn Geography in the Social Studies course. For instance, they learn how many regions there are in our country, the types of climate that prevail in our country, the region-specific agricultural products grown in our country, industrial activities, and the meaning of economic crises.

(P-24-F). My son learns about History in the Social Studies. For instance, where and when the wars in history took place; who those people are who have left their mark in history, the historical figures in national as well as international history; it is the Social Studies course that teaches about our cultural elements from past to the present to my children.

(P-69-F). A student learns about the life of Mustafa Kemal Atatürk in the Social Studies course. The students learn where Atatürk was born and raised, the names of his mother and father, about his education, his heroism, how he founded the Republic, how he bestowed the right to elect and to be elected to the country, and they learn all the beneficial revolutions he introduced through the Social Studies course.

(P-17-M). The students learn everything; manners, respect to one another, their rights, countries law, dress codes, communication, etc. In short, I think students learn everything about our social life in the Social Studies course.

4.3 Question 3: As a Parent, If You Were Consulted Regarding Your Opinions While Preparing the Content of Social Studies Course, What Subjects and Concepts Would You Suggest to Be Taught to Your Child in This Course

Table 4. Themes Reflecting Parents' Views

\begin{tabular}{lc}
\multicolumn{1}{c}{ Themes } & Frequencies \\
\hline Teaching of Historical Subjects Objectively and Correctly & $\mathbf{2 5}$ \\
Patriotism, Love of the National Flag & $\mathbf{1 6}$ \\
Civics & $\mathbf{1 5}$ \\
Economic Resources of our Country & $\mathbf{1 2}$ \\
Cultural Elements & $\mathbf{1 1}$ \\
Etiquette & $\mathbf{1 0}$ \\
Concepts of Freedom, Equality, Rights, Law & $\mathbf{5}$ \\
\hline
\end{tabular}

The parents who participated in the study indicated that the subjects they wished to be taught the most were "Teaching of Historical Subjects Objectively and Correctly" (f:25), "Patriotism, Love of the National Flag" (f:16), "Civics" (f: 15), "Economic Resources of our Country" (f: 12), "Cultural Elements" (f: 11), "Etiquette" (f: 10), and "Concepts of Freedom, Equality, Rights, Law" (f: 5). Responses of the parents to the relevant question are given below. One of the parents indicated that;

(P-26-M). In the Social Studies course, first of all, our children should be taught the value of being a human. The main foundation should be built on this, our cultural codes should be transferred to our children, the virtues of love, respect and tolerance should be instilled by showing the ways of being an honest individual. After they are taught all these, the subjects of history and geography should be taught and children should learn the social studies course through the examples from the lives of our ancestors. Otherwise, I do not think that providing scholastic information will help our children.

(P-37-F). First and foremost, I would want my child to be taught etiquette for our social life. Once you've managed it, the rest will come by itself.

(P-18-F). First of all, I want our students to be taught justice and respect for human rights, but also teach our children the formula of living freely by protecting their own rights. The greatest obstacle in the upbringing of a generation with a sense of justice is that our consciences have been blunted. As far as I am concerned, this is one of the biggest deficiencies in the new generations that our country raises.

(P-13-M). In the Social Studies course, first of all, our students should be given social awareness, the importance of living together and the importance of clamping together in difficult times should be conveyed and the curriculum should be adapted accordingly. In addition to this, our students should be given the love of their country, nation and flag and relevant examples from our history should be provided. It is because our kids do not really know the challenges and difficulties of life. Unfortunately, all of us, maybe knowingly or unknowingly, raise a lethargic 
generation dependent on technology. The students should be told especially about the Gallipoli war so that our children can realize the difficult circumstances of the salvation war and how this was won and our country protected.

(P-61-F). I want our students to be taught about our ancestors, in other words Ottoman History, correctly and properly. It is because we observe that there are TV series on our history on television. But we don't know how much of what we watch is right or wrong. Some experts say that what we watch on TV are right and some others say they are wrong. Therefore, I think that our history, especially the Ottoman culture and civilization, should be the subjects that should be taught most in the Social Studies course.

(P-44-M). In the Social Studies course, our children should be introduced the world in which we live. In addition, they should be taught about the underground and aboveground resources of our country. At least I would want our children to realize the characteristics of the region in which he lived. For instance, I live in Istanbul but I am originally from Erzurum. But every summer I take my children to Erzurum, show them around in my hometown; I want them to recognize the culinary culture, mines, agriculture and livestock activities that Erzurum has. Since the Social Studies course is the main center of these subjects, I would like our children to be taught these subjects in detail in this course. Not only for my hometown, but all the seven regions of our country.

4.4 Question 4: If You Thought of the Social Studies Course as an Organ in the Human Body, Which Organ Would You Describe This Course As? Why?

Table 5. Themes Reflecting Parents' Views

\begin{tabular}{cccc}
\hline Themes & Frequencies & Themes & Frequencies \\
\hline Brain & $\mathbf{2 0}$ & Eyes & $\mathbf{1 0}$ \\
Kidney & $\mathbf{1 5}$ & Stomach & $\mathbf{9}$ \\
Heart & $\mathbf{1 5}$ & Intestines & $\mathbf{6}$ \\
\hline
\end{tabular}

It was observed that the parents who participated in the study likened the Social Studies course to the organs of Brain (f:20), Kidney (f:15), Hearth (f: 15), Eyes (f: 10), Stomach (f: 9), and Intestines (f: 6). Responses of the parents to the relevant question are given below. One of the parents indicated that;

(P-13-M). If the Social Studies course were an organ in the human body, I think it would be the heart. It is because the heart, which is one of the most important organs in the human body, also represents the conscience. A person who starts to live unscrupulously and selfishly cannot be a social person; s/he cannot create the community consciousness. Therefore, Social Studies course undertakes an important mission, such as the heart, in creating community awareness.

(P-14-M). I can define the Social Studies course as the heart of a human being. It is because the heart pumps blood to the whole body to ensure the survival of the human being. Social Studies course also directs a human's life in many areas in order for people to survive.

(P-50-M). I would think of the Social Studies course as the kidney in the human body. The kidney drains all fluids entering into the body. Social Studies course provides a lot of knowledge and information, skills and attitudes about social life by filtering and bringing together many subjects such as History, Geography and Citizenship.

(P-53-F). I would think of the Social Studies course as the stomach in our body. It is because the stomach provides nutrition to the whole body through all the nutrients taken by mouth (sweet, salty, bitter, sour, etc.) in its own structure by disintegrating and digesting them. So, the Social Studies course fulfils a similar function as well. by gathering and blending the information in many fields such as History, Geography, Philosophy, Citizenship, Constitution, etc. within his own body, it allows the individual to adapt to the social life.

(P-22-F). I would describe it as the intestines. Intestines are the place where the necessary minerals are absorbed in the human body. The Social Studies course can be considered as a course where the knowledge specific to many fields come together and is absorbed.

(P-38-M). I would consider the Social Studies as the brain. As for the reason, just as our brain organizes our behaviors by controlling all of our organs, the Social Studies course controls the individual's behaviors related to social life and enables the individual's adaptation to society.

(P-68-M). I would define it as the eyes. It is because we can't see anything without our eyes. That's why the Social Studies course is important. It's like our eyes. So, we cannot see our historical past and the world we live in without the Social Studies course. 
4.5 Question 5: If You Wished to Rank All the Courses in terms of Importance, Where Would You Place the Social Studies Course? Why?

Table 6. Themes Reflecting Parents' Views

\begin{tabular}{lc}
\hline Themes & Frequencies \\
\hline 1.Rank & 7 \\
2.Rank & 8 \\
3.Rank & 23 \\
4.Rank & 20 \\
5.Rank & 17 \\
\hline
\end{tabular}

It was seen that the parents who participated in the study ranked the Social Studies course in the order of importance as follows;1.Rank (f:7), 2.Rank (f:8), 3.Rank (f: 23), 4.Rank (f: 20), and 5.Rank (f: 17). Responses of the parents to the relevant question are given below. One of the parents indicated that;

(P-38-M). I will rank it as the first. It is because, first and foremost, one should be aware of the geography and history $\mathrm{s} /$ he lives in. One should not live insensibly in today's world. Science has no value unless civilization has progressed in the technique. If this is not the case, even if you are ahead of science and mathematics, I think it is not very valuable.

(P-69-F). I'll rank it as the third. It is because I think that other courses are more important than the Social Studies course. For me, Science and Mathematics courses are more important.

(P-33-F). I'll place it in fifth place. Because when I think about the university entrance exam system, I can say that the Social Studies course comes after Turkish, Mathematics, Science and English lessons in terms of importance.

4.6 Question 6: Would You Want Your Child to be a Social Studies Teacher? (Yes-No) Why?

Table 7. Themes Reflecting Parents' Views

\begin{tabular}{cc}
\hline Themes & Frequncies \\
\hline Yes & 23 \\
No & 52 \\
\hline
\end{tabular}

It was seen that the parents who participated in the study answered Yes (f: 23), No (f: 52) to the question of whether they wanted their children to be a Social Studies teacher or not. In other words, the majority of the participants did not want their children to be Social Studies teachers. Responses of the parents to the relevant question are given below. One of the parents indicated that;

(P-6-F). "Yes, I would want. It is because I am aware that the Social Studies course is an important and necessary one. I would be proud to see my child performing the teaching profession in this important branch". Another parent exresses her opinions as follows;

(P-70-F). "No, I would not want. It is because teachers applying for state schools are very difficult to be appointed, and teachers' salaries are low. That's why I would not."

(P-55-F). "No, I would not want. It is because teaching as a profession is not a promising and prospective one. Moreover, the branch of Social Studies as a teaching profession stands no chance." With such comments, the parents drew negative picture for the branch of Social Studies as a teaching profession.

\section{Discussion and Conclusion}

In this study which aimed to identify the opinions of parents of 5th, 6th and 7th grade students about the social studies course, perspectives of the participating parents regarding the research questions are given below.

- Parents associated the concept of Social Studies the most with the concepts of History (f: 32), Geography (f: 32), Socialization (f: 23 ) and Citizenship (f: 15). Some parents (f: 5), on the other hand, stated that they did not understand anything from the concept of Social Studies.

- Parents though that students learnt about History (f: 38), Geography (f: 38), Citizenship (f: 12), Culture (f: 7), Democracy (f: 4), Human Rights (f: 4), Everything (f: 4), Life of Atatürk (f: 4), and Sociology (f: 2) in the Social Studies courses. 
- Parents stated that the subjects they wished children to be taught the most in the Social Studies courses were "Historical Subjects" (Objectively and Correctly) (f:25), "Love of Motherland, Nation, Community and National Flag" (f:16), "Civics" (f:15), "Economic Resources of our Country" (f: 12), "Cultural Elements" (f: 11), "Etiquette" (f: 10), and "Concepts of Freedom, Equality, Rights and Law" (f: 5). The reason for this was that since the Social Studies course was related to daily life, the parents tried to explain that the course harbored the knowledge and information that the students could use in their daily lives. No similar study has been encountered so far that would support the results of the present study.

- However, the results obtained by Akengin and Demirsoy (2011) on the "Views of Fourth and Fifth Grade Students on the Social Studies Course" overlap with the results of this study. In the present study, more than half of the students who participated in the study stated that they could use the subjects they learned in the social studies lessons in their daily lives. Similarly, it is possible to say that the results of recent studies done by Yaşar and Gündoğar-Bayır (2010) and Gömleksiz, Kan, Öner (2012) are in line with the results of this study.

- It was found that the parents participated in the study likened the Social Studies course to the following organs; Brain (f: 20), Kidney (f: 15), Heart (f: 15), Eye (f: 10), Stomach (f: 9), and Intestines (f: 6). The reason for this situation is that the Social Studies course was tried to be explained by the phrase "a course in the form of educational activities of life".

- It was found that the parents ranked the Social studies course in terms of importance as follows; first rank (f: 7), second rank (f: 8), third rank (f: 23), fourth rank (f: 20), and fifth rank (f): 17). When the parents' responses to the previous questions were checked, it was seen that the parents produced statements pointing out the importance of social studies course; however, as far as the responses given to the question of ranking the Social Studies course in terms of importance are concerned, it was seen that this course was ranked in the last place. In this respect, it is seen that there is a contradiction in the opinions of parents about the course. There may be several reasons for this. First of all, a low-profile perspective on verbal courses may have occurred, or it may be due to the fact that occupational groups with a high rate of employment throughout the country are generally chosen from the numerical field. It is because the explanations of the V-54 and V-32 coded parents seem to support this situation. For instance, the parent coded V-54 made the following explanation; "It is because I do not think that the standard deviation score average of the Social Studies course is very high in an exam-based education system. In my opinion, my child should practice more in the Mathematics and Science courses.

- The majority of the parents, Yes (f: 23), No (f: 52), did not want their children to become Social Studies teachers. Even though the parents emphasized the necessity of the Social Studies course in general, it was observed that the parents were not willing to see their children to study and perform this profession. The reasons for this situation seemed to be attributed by the parents to the inadequacy of the teaching profession in terms of income level and the difficulties and distress experienced by the Social Studies teachers in the appointments.

- When the whole study is evaluated in general, it is possible to say that parents had a positive point of view about the Social Studies course. According to the results obtained, the following recommendations can be made to the prospective researchers who will carry out the studies in the future:

- The present study is limited to the Istanbul-Sultanbeyli district. Therefore, relevant studies can be replicated out in districts with different socio-economic levels and even throughout whole the country.

- It should be made clear to the parents that the Social Studies course was not only about history and geography, but included other social science disciplines as well.

- Works aimed at improving the image of the Social Studies course can be carried out by the MEB.

\section{References}

Akbaşlı, S., \& Kavak, Y. (2008). Ortaöğretim Okullarındaki Okul Aile Birliklerinin Görevlerini Gerçekleştirme Düzeyleri. Selçuk Üniversitesi Sosyal Bilimler Enstitüsü Dergisi, 19, 1-21.

Akengin, H., \& Demirsoy, M. (2011). Dördüncü Ve Beşinci Sınıf Öğrencilerinin Sosyal Bilgiler Dersine İlişkin Görüşleri. M.Ü. Atatürk Ĕgitim Fakültesi Eğitim Bilimleri Dergisi, 33, 5-23.

Altunışı, R., Coşkun, R., Bayraktaroğlu, S., \& Yıldırım, E. (2002). Sosyal Bilimlerde Araştırma Yöntemleri. 
Adapazarı: Sakarya Kitabevi.

Aslanargun, E. (2007). Okul - Aile İşbirliği ve Öğrenci Başarısı Üzerine Bir Tarama Çalışma. Sosyal Bilimler Dergisi, $18,119-135$.

Ayva, Ö. (2010). Sosyal Bilgiler Dersi Öğrenme Öğretme Süreci İle İlgili Öğrenci Görüşleri. ICONTE (International Conference on New Trends in Education and Their Implications). ISBN: 978605364 104 9, s.276-282. Retrieved from http://www.iconte.org/FileUpload/ks59689/File/58.pdf (Erişim Tarihi: 05.03.2019, Saat:17:16).

Balkar, B. (2009). Okul Aile İşbirliği Sürecine İlişkin Veli ve Öğretmen Görüşleri Üzerine Nitel Bir Çalışma. Çukurova Üniversitesi Eğitim Fakültesi Dergisi, 3(36), 105-123.

Bayrakdar, M. (2006). Okul Çevre İlişkilerini Geliştirmek İçin Neler Yapabiliriz? İlk ögretmen Ĕgitimci Dergisi, 3, 12-13.

Büyüköztürk, Ş., Kılıç Çakmak, E., Akgün, Ö.E., Karadeniz, Ş., \& Demirel, F. (2013). Bilimsel Araştırma Yöntemleri. Ankara: Pegem Akademi.

Çelenk, S. (2003). Okul Başarısının Ön Koşulu: Okul Aile Dayanışması. İlköğretim Online E-Dergi, 2(2), 28-34.

Çetin, Ş., \& Dinç, E. (2017). Ortaokul Yedinci Sınıf Öğrencilerinin Sosyal Bilgiler Algılarının İncelenmesi. Diyalektolog Ulusal Sosyal Bilimler Dergisi, 16, 241-259. https://doi.org/10.22464/diyalektolog.180

Ceylan, M., \& Akar, B. (2010). Ortaöğretimde Okul Aile İşbirliği İle İlgili Öğretmen ve Veli Görüşlerinin İncelenmesi (Karacasu Lisesi Örneği). Çankırı Karatekin Üniversitesi Sosyal Bilimler Enstitüsü Dergisi, 2, 43-64.

Christensen, L. B., Johnson, R. B., \& Turner, L. A. (2015). Research methods design and analysis (12th ed.). Boston: Pearson Education Limited.

Demirel, Ö. (2011). Öğretme Sanatı-Öğretim İlke ve Yöntemleri. Ankara: Pegem Akademi.

Erden, M. (Tarihsiz). Sosyal Bilgiler Öğretimi. İstanbul: Alkım Yayınevi.

Gömleksiz, M. N., Kan, A. Ü., \& Öner, Ü. (2012). İlköğretim öğrencilerinin sosyal bilgiler dersine ilişkin metaforik algıları. Erzincan Üniversitesi Ë̆itim Fakültesi Dergisi, 14(2), 419-436.

Gülcan, M. G., \& Taner, N. (2011). Öğretmen Görüşlerine Göre İlköğretimde Ev Ziyaretinin Okul Başarısına Etkisi. Mehmet Akif Ersoy Üniversitesi Ĕ̈itim Fakültesi Dergisi, 11(22), 129-144.

Gülsoy, Y., \& Bulut, D. (2016). Ortaokul Müzik Dersine Yönelik Veli Görüşleri (Niğde ili örneği). Journal Of Human Sciences, 13(3), 4944-4958. https://doi.org/10.14687/jhs.v13i3.4138

Kukk, A., Rajalaane, R., Liis Rei, M., \& Piht, S. (2015). Parents Opinions On Homework İn The II Stage Of Primary School (Estonian Example). Procedia-Social and Behavioral Sciences, 171, 134-144. https://doi.org/10.1016/j.sbspro.2015.01.099

Kutluca, T., \& Aydın, M. (2010). Velilerin Matematik Eğitimine Yönelik İlgileri, Tutumları ve Destekleri. Aile Toplum Ve Ë̆itim-Kültür Ve Araştırma Dergisi, 22, 65-78.

Öztürk, C., \& Dilek, D. (2002). Hayat bilgisi ve sosyal bilgiler öğretim programları. In Yay. Haz. C. Öztürk \& D. Dilek(Eds.), Hayat bilgisi ve sosyal bilgiler öğretimi. (ss. 47-81). Ankara: PegemA Yayıncılık.

Safran, M. (2011). Sosyal Bilgiler Öğretimine Bakış. In Yay. Haz. B, Tay \& A. Öcal (Eds.), Özel ögretim yöntemleriyle sosyal bilgiler ögretimi (ss. 1-18). (2nd ed.). Ankara: Pegem Akademi Yayıncılık.

Tay, B. (2010). Sosyal Bilgiler Öğretiminin Dünü Bugünü ve Yarını. In Yay. Haz. R. Turan, K. Ulusoy (Eds.), Sosyal Bilgilerin Temelleri (ss. 3-20). Ankara: Maya Akademi.

Yaşar, Ş., \& Gündoğar-Bayır, Ö. (2010). İlköğretim 5. Sınıf Öğrencilerinin Bakış Açısıyla Sosyal Bilgiler. Ulusal Sınıf Öğretmenliği Ĕ̈itimi Sempozyumu Bildiriler Kitabı, 9, 73-78.

Yıldırım, A., \& Şimşek, H. (2006). Sosyal Bilimlerde Nitel Araştırma Yöntemleri. Ankara: Seçkin Yayıncılık.

Yıldırım, A., \& Şimşek, H. (2008). Sosyal Bilimlerde Nitel Araştırma Yöntemleri (7th ed.). Ankara: Seçkin Yayıncılık.

Yıldırım, A., \& Şimşek, H. (2011). Sosyal Bilimlerde Nitel Araştırma Yöntemleri (8th ed.). Ankara: Seçkin Yayıncılık.

Yin, R. K. (2009). Case study methods: design and methods (4th ed.). Thousand Oaks: Sage Pbc.

Yörükoğlu, A. (1998) Çocuk Ruh Sağlı̆̆l. Basım, İstanbul: Özgür Yayıncılık. 